European Journal of Archaeology

Manuscript received 18 October 2016, revised 15 March 2017, accepted 20 April 2017

The Lives of Houses: Duration, Context, and History at Neolithic Uivar, Romania FLORIN DRAŞOVEAN ${ }^{1}$, WOLFRAM SCHIER ${ }^{2}$, ALEX BAYLISS ${ }^{3}$, BISSERKA GAYDARSKA ${ }^{4}$ AND ALASDAIR WHITTLE ${ }^{4}$

${ }^{1}$ National Museum of Banat, Timişoara, and Institute for Doctoral Studies, Babeş-Bolyai University, Cluj-Napoca, Romania

${ }^{2}$ Institute of Prehistoric Archaeology, Free University of Berlin, Germany

${ }^{3}$ Historic England, London, and Biological \& Environmental Sciences, University of Stirling, $U K$

${ }^{4}$ Department of Archaeology and Conservation, Cardiff University, UK

There is a considerable mix of models for house durations in the literature on Neolithic Europe. This article presents a summary of a formal chronological model for the Neolithic tell of Uivar in western Romania. We provide estimates of house duration and relate houses to other features of the development of this tell, from the later sixth to the mid-fifth millennium cal BC. Three wider implications are discussed: that the house must be contextualized case by case; that house duration gives powerful insights into the sociality of community; and that houses, surprisingly often taken rather for granted in Neolithic archaeology, should be fully integrated into the interpretation of Neolithic histories. From what perspective, anthropocentric or relational, that may best be done, is open to question; while it may be helpful to think in this case in terms of the lives and vitality of houses, the ability of people to create and vary history should not be set aside lightly.

Keywords: Neolithic houses, house duration, Uivar tell, Romania, radiocarbon dating, chronological modelling, historical and relational approaches

\title{
INTRODUCTION
}

In both archaeology and anthropology, the house is acknowledged as a central and recurrent anchor in all aspects of many people's lives. Physically this is where many people dwelled, and socially and conceptually the house is one of the key frames for the grounding of relationships and worldviews. In Neolithic and other prehistoric archaeology, we can trace a burst of interpretive interest in the house from the beginning of the 1990s, as for example in 
Bailey (1990) and Hodder (1990), and continuing since (for example: Richards, 2005; Tringham, 2005; Beck, 2007; Souvatzi, 2008; Hofmann \& Smyth, 2013). Such studies in part drew on anthropological discussions (Bourdieu, 1977; Waterson, 1990: Bloch, 1995; Carsten \& Hugh-Jones, 1995; Joyce \& Gillespie 2000 to cite just a few), picking up, among other themes, the ideas of the biography, agency, and symbolism of the house, the composition of the household, and exploring the usefulness of the house societies model. In all these studies, however, the temporality and history of specific houses are one dimension which has received rather variable attention.

In her article, 'When is a house?', Susan Gillespie (2007: 40) drew general attention to 'various temporal scales, linking microscale processes and practices at the level of households to macroscale and multifaceted processes'. She emphasized that 'houses are in history', which 'means that the outcomes of their members' actions make history, including unintended consequences' (Gillespie 2007: 41; original emphasis). She also noted, with reference to Lévi-Strauss and the house societies model, 'the house as an instrument of rapprochement' between anthropology and history (Gillespie, 2007: 41). There is a gap, however, between these laudable general claims and the detail available for close examination of the durations, contexts, and histories of Neolithic houses in south-eastern Europe, which are the particular focus of our article. Gillespie's important contribution was published in the much-cited edited collection, The durable house (Beck, 2007), which deals with the usefulness of the houses societies model (which is not our principal concern here). There, the notion of durability is attached especially to the possibility of the transmission of the house as a concept, moral person, and social institution. Probably the majority of prehistorians would tend also to accept the notion of houses that lasted, for variable but often imprecisely quantified periods, and that is what we want to challenge.

Our contribution will first very briefly review what has been claimed in the literature about the duration of Neolithic houses in south-eastern Europe and beyond, and then go on to present formally modelled results which offer unusually precise chronologies for the houses in the Neolithic tell of Uivar in western Romania (from the later sixth to the earlier fifth millennia cal $\mathrm{BC}$ ). These house lives can and must be seen in context, drawing on other features of the tell, including a succession of encircling ditches, some of them at least interpreted as defensive. Overall, we offer a detailed and dynamic biography for this site, which we believe presents, more or less for the first time in this type of archaeology, the kind of specific history - those people in that place at those times - to which Gillespie has alluded in general terms. This way of proceeding has many implications, which we go on to discuss. 
Amongst these, an important clash is emerging, we believe, between historical and relational or ontological approaches. Although many researchers now advocate sharing or distributing agency across the spectrum of people, animals, things, and materials that are seen to constitute social worlds, we do not want to surrender the opportunity to write detailed histories of sites like Uivar - detailed narratives with plot, driven by people - just when these begin to come within our grasp. We will discuss how houses are caught up in this debate.

\section{The Duration OF THE House}

Carsten and Hugh-Jones (1995: 3) noted that houses can get taken for granted, for a series of reasons and in all manner of ways. How long do houses, in all their varieties of form, kind, and membership, last?

In south-eastern Europe, a range of estimates of house duration has been suggested, in the contexts of both tells and flat settlements (e.g. Chapman, 1997; Souvatzi, 2008). Since the chronology of tells has rarely been established precisely, there have unsurprisingly been varied estimates of the duration of occupation levels in tells and the buildings they contained, for example at Vinča-Belo Brdo, Serbia (Chapman, 1981; Stevanović \& Jovanović, 1996). Estimates there have run as high as about 50 years for each inferred structural horizon, though not for the buildings within them (Chapman, 1981: 10); probably fewer than 15 years are suggested by a formally modelled estimate for one building in the last certain Neolithic structural horizon at Vinča-Belo Brdo (Tasić et al., 2015). Flat settlements do not have the same apparent emphasis on continuity as tells, and at least in the case of Opovo, Serbia, lightly built structures have been equated with shorter occupation periods than on tells, though that difference has not been quantified (Tringham et al., 1985). Modelled estimates for house duration of around 30 years have also been suggested for the tell at Okolište, Bosnia (R. Hofmann, 2013: 473), though on the basis of fewer than 30 radiocarbon dates, mainly on samples of disarticulated animal bone, for a sequence of some $4 \mathrm{~m}$ of tell deposit. Very few sites (note also Polgár-Csőszhalom, Hungary: Raczky et al., 2015) have had their chronology rigorously tested, which sits uneasily alongside the otherwise sophisticated discussions (including the possibility of deliberate destruction, especially by fire: Tringham, 2005) of the roles and meanings of the house in Neolithic south-eastern Europe.

There is also a wide range of models of house duration in other European Neolithic archaeology. One well-known example is the Hofplatzmodell for sixth-millennium cal BC LBK (Linearbandkeramik) timber longhouses, according to which such houses existed within their own space and were replaced regularly at intervals of 25-30 years (summarized and 
reviewed in Zimmermann, 2012). This has been challenged with an alternative model of layout in rows and durations of 70 years or more (Rück, 2009). The debate on this issue is ongoing, but the point to underline here is that neither the range of durations nor the possibility of variation through space and time (Lenneis, 2012) have been properly tested (nor will it be easy). In the Alpine foreland of the fourth and third millennia BC, dendrochronology has established much more reliably a series of mainly brief lives for well-built timber houses, often over a span as short as 10-15 years (Ebersbach, 2013). The end of some buildings may have been hastened by damage caused by fluctuating water levels in the lakes beside which many were sited, and others by fire, but it has been emphasized recently that, despite our perception that the Neolithic saw a shift to a sedentary existence, the permanence of structures seems not to have been a factor valued here (D. Hofmann, 2013); greater continuity can be found in the context of local settlement networks and local landscapes (D. Hofmann et al., 2016).

We also note in passing that the anthropological literature often appears either to neglect the duration of houses altogether - a convenience of the ethnographic present - or to offer rather anecdotal observations (see Waterson, 2013: 374). Some studies stress longevity and the process of ageing, others emphasize relative brevity, while an interesting third strand has explored the circumstance of deliberate destruction, truncating use-lives (among others: McIntosh, 1974; Waterson, 1990; Bloch, 1995).

If there is a single thread running through all this diversity, it is that context, social practice, and history are key to understanding the house, but without precise chronology, these dimensions are hard to grasp (see also Souvatzi, 2012: 178-84). With that claim, we move to the case study of Neolithic Uivar.

\section{The Uivar Tell}

The Uivar tell lies in the Banat plain in western Romania, on a major branch of the Timiş valley (Draşovean \& Schier, 2010; Figure 1). It is one of the many settlement mounds or tells which appeared in the Carpathian basin from the later sixth millennium cal BC, formed by repeated occupation and rebuilding on the same spot (Bailey, 1990). Investigated by a joint Romanian-German team from 1998 to 2009, the site proved to consist not only of the visible tell, covering an area of some 3 ha and with a vertical stratigraphy of $4 \mathrm{~m}$, but also several encircling ditches revealed by geophysical survey, the outermost of which appears to form an ellipse of 350 by $200 \mathrm{~m}$ in extent and a total area of some $12 \mathrm{ha}$; there were also further features between the tell and the outermost ditch (Figure 2). The site was excavated by a 
series of trenches, sampling both the tell and the ditches, and in three instances the off-tell occupation in between.

The geophysical survey gave a view of the layout of the top of the tell, with generally many closely-set buildings, in a more or less regular, concentric layout (perhaps with an empty central space), many of which are thought to have burnt down as they appeared as strong anomalies in the geophysical plot. The excavated trenches on the tell uncovered much smaller areas, but showed a succession of buildings, again closely set, from the bottom to the top of the occupation. There were no visible hiatuses in this sequence, but successive levels, or 'building stages', were marked variously by burning or levelling (Figure 3). Successive levels appear to follow broadly the same orientation and spacing. The buildings in question were rectangular, and post-framed, with the walls often further defined by foundation or bedding trenches; usually the walls would have been made of wattle and daub rather than solid planking. Up to $12 \mathrm{~m}$ long and $6 \mathrm{~m}$ wide, these houses were normally subdivided into two or three rooms. Some buildings had two storeys, either over their whole length or just part of it; in the former case, subdivision into rooms also occurs. The general trend is from more heavily built buildings early in the sequence to lighter constructions later on, probably relating to changes in the supply of timber, as primary forests were gradually converted into secondary ones (Schier, 2009: 220). Internal features include hearths, clay ovens and bins, large storage pots, small raised platforms, and what are thought to be small cult settings or shrines (Figure 4). There is some evidence for painted walls, and for repeated re-plastering of internal wall surfaces. Domestic material was found in the houses and in the levelling layers, including pottery, stone and bone tools, loom weights, querns, and occupation debris included animal bone, charred plant remains, and charcoal. Abundance varied between burned and unburned houses. There is no doubt that these buildings were lived in, perhaps by some kind of family unit, though the composition and variety of the households in question are hard to pin down in any greater detail. Geophysical survey identified burned houses off-tell, and one excavated off-tell example showed a broadly similar architecture, though with an unusual raised floor and surrounding boardwalk (Draşovean \& Schier, 2010: fig. 26); there could be many more such off-tell buildings, unburned and not so far detected beneath some $1.4 \mathrm{~m}$ of colluvium.

Ditch circuits were found from the edge of the Uivar tell outwards (a finding now common in south-eastern Europe following extensive geophysical survey). The Uivar survey suggests that these were largely continuous, though small gaps can be seen; one entrance was partly excavated close to the tell. The ditches vary in width and depth: for example, close to 
the tell, the first ditch (F1237) was more than 3 m deep, though its width could not be ascertained. Another ditch of unknown dimensions succeeded this (F1053). The largest ditch (F1043=F1054), almost $7 \mathrm{~m}$ wide and $4 \mathrm{~m}$ deep, probably fronted by a plank wall, was still later. Another ditch (F1029) runs parallel at a few metres of distance, with a horizontal plank wall along its inner side. The outermost ditch was 4-6 m wide and 2-2.5m deep, with a backing palisade, and another substantial ditch fairly close inside its circuit. Other ditches and palisades were investigated. The amount of material in the fills of the ditches varied; generally, those close to the tell had more abundant remains than those further out. Cut into alluvial subsoil, these would presumably have become filled quite quickly by natural processes; evidence for cleaning or recutting was only observed in one trench. Such circuits of ditches could have had a variety of roles, which need not have been mutually exclusive. They could have served to define, draw attention to, and generally enhance the look of the settlement; this would apply to ditches both close to the foot of the tell and further out. They could have kept animals out of the close-set buildings of the settlement, and, conversely, within the confines of the outer circuits. But their scale, numbers and frequent remodelling also strongly suggest that they had a defensive function (Figure 5; Draşovean \& Schier, 2010, 172), not perhaps against prolonged aggression, but as protection against surprise or quick attack.

The Uivar site can be related to a shifting set of cultural affiliations or networks, best seen in the changing styles of its pottery. In brief, its earlier levels contain pots which can be assigned to the Szakálhát style typical of adjacent southern Hungary (Kalicz \& Makkay, 1977); from building stage 3b onwards, pottery of Vinča C1 and then C2 style appeared, forming part of a network centred in Serbia (Schier, 1996); and in some of the uppermost features, pots of Foeni style have been found, relating to a distribution across the Banat and to the east and north (Draşovean, 2009).

\section{The Uivar Chronology: Curriculum Vitae of a Tell}

Site stratigraphy, material culture, radiocarbon dates on short-life, single-entity samples, and formal Bayesian modelling (Bayliss \& Whittle, 2015, with references) provide a powerful framework for constructing a refined chronology of the Uivar tell's biography. The chronological model for Neolithic occupation at Uivar combines a total of 182 radiocarbon dates with the archaeological sequence, crucially with the 4 metres of vertical stratigraphy through a series of 11 building stages through the tell excavated in Trench I. It has been constructed using OxCal v4.2 (Bronk Ramsey, 2009; Bronk Ramsey \& Lee, 2013) and is 
fully discussed in Schier et al. (forthcoming, figs 6.9 and 6.12-22). The tell was occupied from the fifty-second to the forty-seventh centuries cal BC. Here we concentrate on the chronology of the houses in Trench I (with some input from Trench II for the uppermost building stages) and the series of ditch circuits around the tell produced by the Bayesian modelling (Figure 6 and Table 1). It is not possible to correlate the partial sequences of other trenches by direct stratigraphic comparison, since the trenches are too far apart, and the seriation of the pottery from Trenches I, II, and XI has yet to be completed. Nevertheless, Figure 8 represents a provisional attempt to correlate the vertical stratigraphy in Trench I (and partly Trench II) with the features revealed in other trenches.

The refined dates for the use and demise of the successive houses on the Uivar tell give us much more precise estimates for the duration of their use than normally achieved. As Figure 7 shows, house durations demonstrably varied and were not uniform, as the archaeological models noted above too often suggest. Some durations were shorter (in building stages $5 b, 5 a$, and $3 a$ ), and others longer (in building stages $4 b$ and $4 a$ ), the spans of use ranging from a decade or so to up to some 50 years. Building stages $3 \mathrm{~d}$ and $3 \mathrm{c}$ had to be combined as a single value in the modelling (no dateable material could be located from stage 3c), but its total duration can be broken down into two, given the evidence for extensive repairs through the thick level in question rather than the more usual levelling and rebuilding. Building stage $2 \mathrm{~b}$ is the longest-lasting, with a probable duration of some 80 years.

There is an apparently cyclical pattern of alternating shorter and longer durations, from the shorter lives of the early houses in stages $5 \mathrm{~b}$ and $5 \mathrm{a}$ to the longer biographies of the houses in stages $4 \mathrm{~b}$ and $4 \mathrm{a}$, from the two phases of stage $3 \mathrm{~d}+\mathrm{c}$ to the longer existence of stage $3 \mathrm{~b}$, followed in turn by the briefer duration of stage $3 \mathrm{a}$ and finally the longest span of all, building stage $2 \mathrm{~b}$. The uppermost Late Neolithic building stages $2 \mathrm{a}$ and $1 \mathrm{f}$ consist of some foundation structures, but they are heavily disturbed by mediaeval pits and thus have provided little dating evidence.

All the burnt houses (in stages $4 \mathrm{~b}, 4 \mathrm{a}$, and $2 \mathrm{~b}$ ) were longer-lasting compared to the other houses in the Uivar sequence. A clear correlation with the sturdiness of these structures is unlikely, since the overall trend through time was from heavier to lighter buildings; therefore, the duration of use is probably not simply explained by the durability of the houses. A second layer of flooring, some 6-8 $\mathrm{cm}$ thick and covering both the ground and upper floors, had been laid in houses $4 \mathrm{~b}$ and $2 \mathrm{~b}$. This must have considerably raised the weight to be supported by the internal timber framework, which had been designed to be sufficiently stable right from the beginning. But the unburnt houses of phase $3 \mathrm{~b}$ also show evidence of 
concern for their future stability, as shown by carefully laid worked planks, acting as support for the ground floor made of loam. The house architecture shows that stability was intended and a long house life expected. The diversity of construction thus does not reflect different life expectancies: the 'biographical diversity' of Uivar houses instead suggests social discontinuities or external causes for their differing lifespans. Of course, we must bear in mind the possibility of accidental burnings at irregular intervals. Houses $4 b-1$ and $4 a-1$ were distinct. Both are substantial, with several rooms; house 4b-1 had two storeys, as house $2 b-1$ did. House 4b-1 was re-plastered up to five times. It contained intriguing evidence of a small shrine or special setting in the westernmost room on the ground floor, and a portable altar, as well as a re-plastered floor, imported pottery, and a loom on the upper floor. House 4a-3 contained a clay head originally attached to a wall, and a clay table. These three structures need not be construed as identical, nor should we ascribe a single special function to them; but the evidence does suggest a correlation between their longer durations and the effort invested in building and furnishing them. Further detail will be available in due course in the site monographs.

The frequency of house burning is striking in the Neolithic period in south-eastern Europe. Different opinions (e.g. Chapman, 1999; Stevanović, 2002; Tringham, 2005) are held about whether we can distinguish between individual or wider house burnings, between accidental and deliberate burnings, and, in the latter scenario, between differing motivations such as aggressive acts among and between households and communities or the ritual and symbolic ending of individual households, say at the end of household lives or on the death of heads of households. In the case of Uivar, the small area of the excavation trenches precludes definitive judgment, but the geophysical survey showed numerous anomalies indicating burned buildings, which certainly suggests that burning was extensive in the upper level of occupation on the tell; this is consistent with the excavated evidence at the end of building stage $2 \mathrm{~b}$. This cannot be examined over the same kind of area for the two earlier burnt horizons, at the end of building stages $4 \mathrm{~b}$ and $4 \mathrm{a}$; nevertheless the evidence from the trenches suggests that more than single buildings were burnt down.

This burning evidence constitutes an important link in the interpretation of the Uivar site. The width and depth of the encircling ditches and their frequent combination with palisades suggest that these circuits were defensive, even if also partly symbolic. These ditches have also been dated, though we could not achieve as much precision for them as for the houses (given the lack of a constraining stratigraphic sequence and a paucity of datable material). Their sequence can be correlated with that of the houses, albeit with greater 
uncertainty (Schier et al., forthcoming). As Figure 6 shows, the earliest circuit was F1237. This was probably present from the beginning of the occupation, and it seems to have been the defensive system that was there at the end of stage $4 \mathrm{~b}$, though we could not tell for sure if it had been constructed in building stage $5 \mathrm{~b}, 5 \mathrm{a}$ or $4 \mathrm{~b}$. Putting together the potentially extensive burning of houses at the end of building stage $4 \mathrm{~b}$ and the demise of the early ditch system leads us to see a first dramatic episode in the site biography (Figure 8, 4b).

Other ditch circuits follow. F1236=F1238 and F1219 may well belong together (Figure 6). We were again unable to relate them precisely to building stages, but they probably go with building stages $4 \mathrm{a}$ or $3 \mathrm{~d}$. It is possible to see a correlation between the end of these circuits and the burning, again potentially extensive, at the end of building stage $4 \mathrm{a}$ (Figure 8, 4a). Circuits F1055 and F1158 are likely to have followed, and they probably go with building stages $3 \mathrm{~d}+\mathrm{c}$ or $3 \mathrm{~b}$. In these instances, there is no question of relating the demise of ditch circuits with house burnings, since none were observed in the excavated parts of the tell in those stages. Then the outer circuit, ditch F1053 (with its possible gatehouse, house A) and ditch F4045/F4051 were dug, all probably related to building stage 2b (Figure 8). If burnings and the end of defensive circuits can legitimately be linked, then these were the ditches that could have failed at the end of the long-lasting building stage $2 b$, which certainly did see extensive burning.

The most impressive of all the Uivar ditches, F1043/F1054 (Figure 9), probably marks the re-building of the defences following this fire, joined by circuits F2108 and the palisade in Trench IX. The ditch F1029 has been modelled here as earlier than F1043/F1054, though other possibilities will be discussed elsewhere (Schier et al., forthcoming). All these are later than the major fire at the end of building stage $2 \mathrm{~b}$, and appear to have been in place during the use of house 2a, house 3208 on the tell in Trench XI (and probably also of the undated burnt house 3172/3173), and of house 2245 in Trench XV in the area of 'flat' occupation beyond the tell (Figure 8). The latter, which cannot be dated very precisely, may even be contemporary with the final Neolithic stage 1f, to which only few foundation structures on top of the tell can be attributed.

Despite the uncertainties about the chronology of the ditches at Uivar and the difficulties of correlating them precisely with building stages, the overall importance of the sequence seems clear. The significance of the duration of buildings cannot be assessed out of context. One further factor in the fate of houses may have been the success of settlements and the efficacy of defensive ditch circuits. Ditches were dug from an early stage of the tell, and, given their size (and thus the amount of time that it would have taken for them to silt up 
completely), there was probably some sort of enclosure throughout the life of the tell. Whether things were left to decay when the need for them was less pressing is an open question. The occupants of Uivar seem to have chosen ditch construction rather than maintenance and repair; could that mean that the defences were only constructed in response to particular threats? It is striking that the longest-lasting building stage, $2 \mathrm{~b}$, coincides with the largest ditch circuit. The very durability of the houses which end by being burned may also argue against accidental fires, which could presumably have occurred at any point in their lives. Ditches were also in use at the very end of occupation, when houses on the tell may have been much scarcer and others had perhaps spread out on to the area of flat settlement beyond it.

\section{DisCUSSION}

The first of three important wider implications is that the house must be contextualized case by case, and at different points in the sequence in each and every case. After appropriate, detailed, formal analysis at Uivar, we can offer a median duration of 36 years for the lives of houses, but that figure taken on its own masks the variation and possible cyclicity of pattern in house durations through the Uivar sequence; it also removes house histories at any one stage of the sequence from their context and relationship to other features such as the ditch systems surrounding the tell. Could the apparent brevity of early houses at Uivar, for example, be related to their deliberate destruction? To note just one suggestive analogy, people built large and impressive structures, with projecting high gables, in Toraja, Sulawesi; much effort and skill were invested in their construction (Waterson, 1990: 163-66). But many were dismantled, commonly at intervals of 25 years or so, and often before it was necessary from a functional point of view; this was an essential part of the process by which the house gained history and significance, such that its descendants came to regard it as an origin house (tongkonan) (Waterson, 2013: 389-90).

We believe that similar variation in house duration can be found in other tells (Tasić et al., 2015, 2016), but given the diversity noted, we do not exclude the possibility of a stable duration of house lives in other situations. The wider message, simple but important, for Neolithic archaeology is therefore to mistrust the generalizing models for house durations often advocated in past research. That must surely apply to tells and flat settlements in southeastern Europe. And elsewhere, variation within and among LBK longhouse settlements through time, for example, may have been more extensive and more dynamic than often modelled in the past. Put bluntly, we have had to work hard to achieve the Uivar chronology 
presented above, and it will take a considerable collective effort across the discipline to create comparable case studies in the coming years.

A second major implication of our analyses at Uivar is that house and household duration gives powerful insights into the sociality of tell and related communities. We do not simplistically equate a house with household - since households could be distributed over more than one structure - but argue that variation in house duration as modelled for Uivar speaks for variation in household history (Souvatzi, 2008, 2012). Differences in duration may also be influenced by the varying economic or social meaning of architectural compounds. Houses $4 \mathrm{~b}$ and $4 \mathrm{a}$ at Uivar were both accompanied by a smaller house along their southern wall, connected by a wooden floor. This situation suggests that in this case a household consisted of two buildings, rebuilt at least twice on the same spot. Other houses, however, did not provide any evidence for connected or secondary buildings. Generalizing, houses of rather uniform size and construction are the main constituent of tells in the cultural setting of Uivar; unusually large buildings or formally defined spaces within them are extremely rare. Houses here and on other south-eastern European tells were closely grouped, variously forming rows, clusters, and other layouts; they did not exist on their own. There may well have been neighbourhoods or other kinds of differentiation within tell layouts, as well as a sense of overall spatial order; in either case, there is a communal dimension to the setting of houses. That said, the symbolic and affective dimensions of community can be complicated and at times contradictory. Community must be worked at (Birch, 2013: 8; Canuto \& Yaeger, 2000), may be riven with difference (Hoggett, 1997), and can be fragile (Amit, 2002). The disadvantages of living close together are a recurrent theme in other documented cases, with tensions, for example between the interests of individuals or kin groups and the ethos of community, between the values of generosity and the impulse to aggrandisement, or between corporate ceremony and esoteric knowledge (Pluckhahn, 2010: 100). Social tensions can be mitigated or managed through shared practice, or through authority figures and institutions (Pluckhahn, 2010: 102). But community is often short-lived (Bandy, 2010: 23). The breaking up and relocation of substantial villages are reported in various situations among the Iroquois after only 10-15 years (Creese, 2012: 368) or 15-30 years (Birch \& Williamson, 2013: 15354). Early Mesa Verde villages have been called 'social tinderboxes', which rarely lasted beyond 30-70 years or one to three generations, as established with precision by dendrochronology (Wilshusen \& Potter, 2010: 178).

In comparison to these examples, tell settlements, with their demonstrably long histories and mostly a lack of hiatuses, stand out as markedly successful communities which 
held together for surprisingly long periods. The detail of how this was achieved is very revealing, as seen in our date estimates for Uivar, which appear to indicate a series of ups and downs (though we have already noted that brevity could have been deliberate, at the start of the sequence, to create a sense of antiquity). Much further and more detailed analysis is required in other situations within Neolithic Europe, but by comparison with elsewhere, the longer durations in the latter part of the Uivar sequence may reflect an unusually extended stretch of house occupancy.

The third and final implication is that houses, especially when precise chronologies are worked out, should be more fully integrated into Neolithic histories, as already recommended by Gillespie (2007). Although key to many Neolithic people's lives and worldviews, the house has often been taken rather for granted in interpretations of the period. People were settled, or were settling down, this argument goes, and so unsurprisingly had houses as a result; at other times, more fluid conditions led to fewer houses being used, or even none that are detectable archaeologically. We often appear to have been content with a distinction between house-rich and house-poor periods, with interpretation focused on the practical and symbolic dimensions of houses within static blocks of time within a culturehistorical framework, of the order of centuries. If the formal modelling now carried out at Uivar (and similar exercises being conducted on other sites) show much more precisely ordered and dated settlement biographies, involving houses at the core of these sequences, what kind of history does that suggest?

For us, the kind of narrative now open to construction fundamentally involves people, households, communities, and others, including both potential allies and enemies. As a precisely dated settlement, Uivar stands alone in its immediate setting, and, in the present stage of research, we must go much further afield in the Carpathian Basin for comparable examples, such as Vinča-Belo Brdo (Tasić et al., 2015, 2016) and Alsónyék (Bánffy et al., 2016). We note the potential of other sites in the wider region for further chronological refinement in the future (e.g. R. Hofmann, 2013; Raczky et al., 2015), and one can envisage, perhaps after another generation of research or more, a landscape full of precisely dated sites; with tell settlements in the Carpathian Basin especially in mind, we should eventually be able to follow in close detail the conditions of their emergence, their development and finally their abandonment in the middle of the fifth millennium cal BC, probably in the 47th and 46th centuries cal BC in particular (Borić, 2015). For us, this would be a history of interaction between people, in households, neighbourhoods, communities, alliances, and hostile relationships, engaged in establishing security, competing for position, and living out the 
beliefs and values characteristic of the time. With enhanced chronological precision, we could hope to write such a history at both a micro- and a macro-scale (see Robb \& Pauketat, 2013: fig. 1.1; Mímisson \& Magnússon, 2014).

We believe that there are also further important consequences to discuss, which go beyond this particular case study, and which concern possible future directions of archaeological interpretation as a whole. Whatever the difficulties involved in achieving the kind of multi-scalar perspective sketched above, this would be very much a people-centred view: a history about the agency of people, and in specific circumstances. This is a view shared by virtually all historians; John Lewis Gaddis suggests that historians 'generalize for particular purposes', whereas social scientists 'tend to embed narratives within generalizations' (Gaddis, 2002: 62, original emphasis). Anthropocentric accounts, however, have been much challenged in the recent literature, across several disciplines. As Marshall and Alberti have put it, 'an ontological turn is underway ... worldviews are being discarded in favour of worlds' it (Marshall \& Alberti 2014: 19). Collectively, a diverse bundle of concepts directly challenges an anthropocentric view of the world, which must also undermine a conventional understanding of historical narrative, at whatever scale is chosen.

One early generalizing account, concerned with the development of settlements over the long term and at a global scale, was set out by Michael DeLanda in A Thousand Years of Nonlinear History (1997). This advocates flows and meshworks, ultimately at a timescale of millennia (DeLanda, 1997: 259), even though more precise dates are quoted in the individual chapters; 'our individual bodies and minds are mere coagulations or decelerations in the flows of biomass, genes, memes, and norms ... we might be defined both by the materials we are temporarily binding or chaining to our organic bodies and cultural minds and by the timescale of the binding operation' (DeLanda, 1997: 258-59) gives a flavour of the nature of this treatment.

A recent account of houses, centred on the early Neolithic settlement of Çatalhöyük in Anatolia, proposes extensive entanglement between people and houses, from an etic and seemingly universalizing point of view (Hodder, 2012). Using notions not only of non-flat entanglement but also of entrapment, stickiness, and practical messiness, and linking all these closely to notions of time, Hodder (2012: 214) argues that 'the unruliness of things and their complex temporalities entrap humans into forms of care and maintenance', with emphasis on 'the networks of entanglement that make possible and constrain certain forms of agency and certain forms of agent' (Hodder, 2012: 215). Hodder further asserts that 'in their objectness things also have primary agency' (2012: 216). In relation to the houses at Çatalhöyük, his 
view is that their construction and maintenance 'drew people into specific forms of relationships, and the gradual decay, slumping and transformation of houses impinged on human lifeways' and that houses 'became key to the maintenance of social relationships that were tied into histories'. Finally, 'humans were increasingly drawn into an entangled web of human-material dependencies in which houses played their part' (Hodder, 2013: 350-60).

We lack the space here to set out all the many and varied sources behind the ontological or relational perspective as a whole, or its many current applications, but we do want to discuss how it affects our view of houses, and the incorporation of houses into what we have called Neolithic histories. First, we note that so far there has been rather little critique within archaeology of the relational approach in general; that is typical enough for the comparatively early stages of the application of a new set of ideas. John Barrett (2014: 68-72 and 2016; but see also Vigh \& Sausdal, 2014; Van Dyke, 2015; Fowles, 2016) has maintained the value of keeping a distinction between different qualities of humanness and between living and non-living things; he has argued that the agency of things is too indeterminate. Given that Heidegger, for example (quoted in Watts, 2013: 8), regarded people as 'world-forming', animals as 'poor in world', and things as 'worldless', we should be very wary of flattening all the concepts noted into a single unified theory. It is far from clear whether the terminology used is emic or etic (as noted by Bird-David, 2006: 35), and, controversially, there is potential for confusion between ontology and epistemology; it sometimes appears as if the deployment of 'ontology' covertly posits some kind of essentialist or universal relationship between or among constituents of the world (Thomas, 2015), in contrast to the notion of epistemology which denotes a particular, contextdependent, belief in things being as they are (though this distinction can be disputed: Scott, 2006: 53-54; see also Carrithers, 2010).

Whether ontology or epistemology is preferred, it seems to us that there is a sense in much of the ontological turn of a universal kind of perspective being advocated (note again Gaddis, 2002: 62), and that can seem closest to an animist or animic view of the world (BirdDavid, 2006; Scott, 2006; Ingold, 2011). According to this, all humans are agents, but there are agents other than humans alone (Ingold, 2013: 246); 'other-than-human' persons may take many guises (Hallowell, 1960). But that immediately raises the difficulty that distinctions can be made within animic or animistic worldviews, and that animism can also be distinguished from, for example, totemism, shamanism, and 'perspectivism' (Descola, 2005; Bird-David, 2006). If, by contrast, we revert to the view that there 'really' is some kind of fundamental, underlying relationship between people and other constituents of the world, 
that ignores the fact that many people, emically, have seen such connections in very different ways, at different times, and in different places. Even within the nexus of ontological approaches, there are divergent views about what constitutes material agency. Though a 'flat ontology' is asserted by some (DeLanda, 2004: 58; van der Veen, 2014: 809, claiming 'equal agency' among people, plants, animals, material culture, and environment), it is not universally agreed that people, animals, and things act or have effects in the world in the same ways (Ingold, 2011: 89-94; Watts, 2013: 7).

Houses are caught up in this debate too. We do not have to go far to find examples of emic belief in the vitality of houses. Varying notions in Java, the Malay peninsula and South Sulawesi, for example, of a pervasive life-force are attached to a very wide range of living things and 'inanimate' objects, from plants, animals, and humans, to mountains, rocks, heirlooms, and textiles - and to houses. Such vitality of houses is seen as interdependent with the vitality and health of their occupants; houses were capable of being offended by inappropriate behaviour. House vitality can be traced back to that of trees in the wild and to the construction process, as well as to the house being thought of and named in terms of the body (Waterson, 1990: 115-21). There are plenty of other ethnographic examples in which 'houses and persons frequently bleed together both conceptually and experientially' (Creese, 2012: 365). Among the Northern Iroquois in the seventeenth century AD, people and their longhouses were perhaps even more closely bound together. Wendat persons were thought of as 'contingent and changeable wholes' (Creese, 2012: 371) and houses too may have been considered to be ensouled entities, closely bound up with people and associated with important war and peace captaincies (Creese, 2012: 372).

How far, however, can the agency of the house be taken? Indonesian houses become animated through having people living in them, in various social forms closely associated with the notion of the house (Waterson, 1990: 136, and chapter 7). Accounts of the Huron stress the importance of warfare, as a means to revenge and to establish the position and voice of younger men especially, as well as of the open councils in which decisions to act (to make friends or to attack enemies) were taken on a more or less egalitarian basis (Trigger, 1976: 68-69). Can we not say that in the end, whatever the closeness of the linkage with houses, it was people who chose to act, or indeed not to act, in particular ways in specific circumstances?

The notion that Neolithic houses in south-eastern Europe could have had concepts of vitality attached to them is attractive; in the Republic of Macedonia, there are even house models topped by prominent anthropomorphic representations (Naumov, 2013). In Uivar 
there is evidence for foundation rituals, as some house trenches contained concentrations of cattle bones, fragments of clay figurines, and in one instance half of a clay mask (Schier, 2006). In the very different context of the circumpolar North, dancers 'wear animal masks which bring the spirits into life amidst the audience' (Bird-David, 2006: 36) and perhaps something similar can be envisaged for the striking though enigmatic mask found in Phase $2 \mathrm{a}$ at Uivar, within the foundation ditch of house H2a-1 (Schier, 2006: 228-30). Such putative vitality may have been a quality ascribed to tells in general, since their rising mounds, with the close-knit assemblage within them of people, houses, animals, and an abundance of things, could plausibly have been thought of not only as alive but also as growing.

This does however not counter the objection that it would most plausibly have been people - including people who were not inhabitants of Uivar-who took the decisions to end house lives, which included burning. On the other hand, there is no need to dispute the general claim that people and houses were 'entangled' at Uivar and similar sites, though this may ultimately be nothing more than an elaborate re-statement of the fact that houses were a central part of their culture and lifeways. Likewise, resorting to the operation of the total assemblage of people and things rather than just individual constituents (Bennett, 2010; DeLanda, 2016) seems to us to run into the same objection. The Uivar houses certainly required care and maintenance, though in different ways as materials changed through the sequence. Houses of this time could in a sense have 'invited' burning (for all manner of motives), since in the right conditions they would have been spectacularly combustible. But it is hard in the end to disagree with Barrett's point (2014: 69) about the indeterminate nature of material agency or intra-activity.

Is there, finally, room for more compromise or accommodation between relational and historical approaches, as defined here? If we are right to assert that it is the people who choose to act in a particular way, do they nonetheless do so as part of some kind of humanmaterial configuration? Should we follow Ingold (2013: 31, following Deleuze \& Guattari, 2004), and see both organic and non-organic entities as equally 'in life'? In a series of essays, Maurice Bloch (1998) has outlined how people in other settings, principally in Madagascar, appear not to think about the world in a linear, programmed fashion, but in a clumped, context-dependent manner; what people think may never quite be settled, as reflected in the 'long conversation that is Balinese society' in which 'at some time, one notion of time is used, and others, another' (Bloch, 1977: 278). Analysing northern Cree hunters, Scott (2006: 51) has drawn attention to 'a melding of practical-empirical rationality with ethical and spiritual understandings'; as he puts it, 'as the weft of experience entwines 
the warp of culturally available categories, narrative is the weaver' (Scott, 2006: 51). Perhaps people at Uivar and similar sites thought at times of their houses as alive, and perhaps the vitality and personality of houses were one constituent of the decision-making process and one thread in some of the stories they must have told about the birth and death not only of individual houses but also of tells as a whole. But indeterminate entanglements, flows and meshworks do not seem to us to accommodate the full force and implications of the detailed and varied history of house and community in a tell settlement like Uivar, not just within the sequence but also at its beginning and at its end. The house provokes a clash of interpretive philosophies, and we vote for history; the lives of houses are key witnesses.

\section{ACKNOWLEDGMENTS}

Excavations at Uivar were funded by the Deutsche Forschungsgemeinschaft. We thank Penny Bickle, John Chapman, Dani Hofmann, and Andy M. Jones for constructive criticism of an earlier draft of this article; and Stefan Suhrbier and Kirsty Harding for help with the figures. The dating and modelling reported here have been supported by a European Research Council Advanced Investigator Grant (295412), The Times of Their Lives (www.totl.eu), led by Alasdair Whittle and Alex Bayliss.

\section{References}

Amit, V. 2002. Reconceptualizing Community. In: V. Amit, ed. Realizing Community: Concepts, Social Relationships and Sentiments. London: Routledge, pp. 1-20.

Bailey, D.W. 1990. The Living House: Signifying Continuity. In: R. Samson, ed. The Social Archaeology of Houses. Edinburgh: Edinburgh University Press, pp. 19-48.

Bandy, M.S. 2010. Population Growth, Village Fissioning, and Alternative Early Village Trajectories. In: M.S. Bandy \& J.R. Fox,(eds. Becoming Villagers: Comparing Early Village Societies. Tucson: University of Arizona Press, pp. 19-36.

Bánffy, E., Osztás, A., Oross, K., Zalai-Gaál, I., Marton, M., Nyerges, É.Á., Köhler, K., Bayliss, A., Hamilton, D. \& Whittle, A. 2016. The Alsónyék Story: Towards the History of a Persistent Place. Bericht der Römisch-Germanischen Kommission, 94: 283-318.

Barrett, J.C. 2014. The Material Constitution of Humanness. Archaeological Dialogues, 21: $65-74$.

Barrett, J.C. 2016. The New Antiquarianism? Antiquity, 90: 1681-86. 
Bayliss, A. \& Whittle, A. 2015. Uncertain on Principle: Combining Lines of Archaeological Evidence to Create Chronologies. In: R. Chapman \& A. Wylie, eds. Material Culture as Evidence: Learning from Archaeological Practice. Abingdon: Routledge, pp. 213-42.

Beck, R.A. ed. 2007. The Durable House: House Society Models in Archaeology. Carbondale (IL): Center for Archaeological Investigation Press.

Bennett, J. 2010. Vibrant Matter: A Political Ecology of Things. Oxford: Berg.

Birch, J. 2013. Between Villages and Cities: Settlement Aggregation in Cross-cultural Perspective. In: J. Birch, ed. From Prehistoric Villages to Cities: Settlement Aggregation and Community Transformation. New York: Routledge, pp. 1-22.

Birch, J. \& Williamson, R.E. 2013. Organizational Complexity in Ancestral Wendat Communities. In: J. Birch, ed. From Prehistoric Villages to Cities: Settlement Aggregation and Community Transformation. New York: Routledge, pp. 153-78.

Bird-David, N. 2006. Animistic Epistemology: Why Do Some Hunter-gatherers Not Depict Animals? Ethnos, 71: 33-50.

Bloch, M. 1977. The Past and the Present in the Past. Man, 12: 278-92.

Bloch, M. 1995. The Resurrection of the House amongst the Zafimaniry of Madagascar. In: J. Carsten \& S. Hugh-Jones, eds. About the House: Lévi-Strauss and Beyond. Cambridge: Cambridge University Press, pp. 69-83.

Bloch, M. 1998. How We Think They Think: Anthropological Approaches to Cognition, Memory and Literacy. Boulder (CO): Westview.

Borić, D. 2015. The End of the Vinča World: Modelling Late Neolithic to Copper Age Culture Change and the Notion of Archaeological Culture. In: S. Hansen, P. Raczky, A. Anders \& A. Reingruber, eds. Neolithic and Copper Age between the Carpathians and the Aegean Sea: Chronologies and Technologies from the $6^{\text {th }}$ to $4^{\text {th }}$ Millennia BCE. Rahden: Marie Leidorf, 167-227.

Bourdieu, P. 1977. Outline of a Theory of Practice (trans. by Richard Nice). Cambridge: Cambridge University Press.

Bronk Ramsey, C. 2009. Bayesian Analysis of Radiocarbon Dates. Radiocarbon, 51: 37-60. Bronk Ramsey, C. \& Lee, S. 2013. Recent and Planned Developments of the Program OxCal. Radiocarbon, 55: 720-30.

Canuto, M.-A. \& Yaeger, J. eds. 2000. The Archaeology of Communities: A New World Perspective. London: Routledge.

Carrithers, M. 2010. Debate: Ontology Is Just Another Word for Culture. Critique of Anthropology, 30: 156-68. 
Carsten, J. \& Hugh-Jones, S. 1995. Introduction. In: J. Carsten \& S. Hugh-Jones, eds. About the House: Lévi-Strauss and Beyond. Cambridge: Cambridge University Press, pp. 1-46.

Chapman, J. 1981. The Vinča Culture of South-East Europe: Studies in Chronology, Economy and Society. Oxford: British Archaeological Reports.

Chapman, J. 1997. The Origin of Tells in Eastern Hungary. In: P. Topping, ed. Neolithic Landscapes. Oxford: Oxbow Books, pp. 139-64.

Chapman, J. 1999. Burning the Ancestors: Deliberate House Firing in Balkan Prehistory. In: A. Gustafsson \& H. Karlsson, eds. Glyferoch arkeologiska rum - envanbok till Jarl Nordbladh. Gothenburg: Institute of Archaeology, pp. 113-26.

Creese, J.L. 2012. The Domestication of Personhood: A View from the Northern Iroquioan Longhouse. Cambridge Archaeological Journal, 22: 365-86.

DeLanda, M. 1997. A Thousand Years of Nonlinear History. New York: Swerve Editions.

DeLanda, M. 2004. Intensive Science and Virtual Philosophy. London: Continuum.

DeLanda, M. 2016. Assemblage Theory. Edinburgh: Edinburgh University Press.

Deleuze, G. \& Guattari, F. 2004. A Thousand Plateaus: Capitalism and Schizophrenia (trans. B. Massumi). London: Continuum.

Descola, P. 2005. Par-delà nature et culture. Paris: Gallimard.

Draşovean, F. 2009. Cultural Relationships in the Late Neolithic of the Banat. In: F. Draşovean, D.L. Ciobotaru \& M. Maddison, eds. Ten Years After: The Neolithic of the Balkans, as Uncovered by the Last Decade of Research. Timişoara: Editura Marineasa, pp. 259-73.

Draşovean, F. \& Schier, W. 2010. The Neolithic Tell Sites of Parţa and Uivar (Romanian Banat): A Comparison of their Architectural Sequence and Organization of Social Space. In: S. Hansen, ed. Leben auf dem Tell als soziale Praxis. Bonn: Habelt, pp. 166-87.

Ebersbach, R. 2013. Houses, Households, and Settlements: Architecture and Living Spaces. In: F. Menotti \& A. O'Sullivan, eds. The Oxford Handbook of Wetland Archaeology. Oxford: Oxford University Press, pp. 283-301.

Fowles, S. 2016. The Perfect Subject (Postcolonial Object Studies). Journal of Material Culture, 21: 9-27.

Gaddis, J.L. 2002. The Landscape of History: How Historians Map the Past. Oxford: Oxford University Press.

Gillespie, S.D. 2007. When is a House? In: R.A. Beck, ed. The Durable House: House Society Models in Archaeology. Carbondale (IL): Center for Archaeological Investigation Press, 25-50. 
Hallowell, A.I. 1960. Ojibwa Ontology, Behavior, and World View. In: S. Diamond, ed. Culture in History: Essays in Honor of Paul Radin. New York: Columbia University Press, pp. 19-52.

Hodder, I. 1990. The Domestication of Europe: Structure and Contingency in Neolithic Societies. Oxford: Blackwell.

Hodder, I. 2012. Entangled: An Archaeology of the Relationships between Humans and Things. Chichester: Wiley-Blackwell.

Hodder, I. 2013. From Diffusion to Structural Transformation: The Changing Roles of the Neolithic House in the Middle East, Turkey and Europe. In: D. Hofmann \& J. Smyth, eds. Tracking the House in Neolithic Europe: Sedentism, Architecture and Practice. New York: Springer, pp. 349-62.

Hofmann, D. 2013. Living by the Lake: Domestic Architecture in the Alpine foreland. In: D.

Hofmann \& J. Smyth, eds. Tracking the Neolithic House in Europe: Sedentism, Architecture and Practice. New York: Springer, pp. 197-227.

Hofmann, D. \& Smyth, J. eds. 2013. Tracking the House in Neolithic Europe: Sedentism, Architecture and Practice. New York: Springer.

Hofmann, D., Ebersbach, R., Doppler, T. \& Whittle, A. 2016. The Life and Times of the House: Multi-scalar Perspectives from the Neolithic of the Northern Alpine Foreland. European Journal of Archaeology 19. Doi: 10.1080/14619571.2016.1147317

Hofmann, R. 2013. Okolište 2 - Spätneolithische Keramik und Siedlungsentwicklung in Zentralbosnien. Bonn: Habelt.

Hoggett, P. ed. 1997. Contested Communities: Experiences, Struggles, Policies. Bristol: Policy Press.

Ingold, T. 2011. Being Alive: Essays on Movement, Knowledge and Description. London: Routledge.

Ingold, T. 2013. The Maze and the Labyrinth: Reflections of a Fellow Traveller. In: C. Watts, ed. Relational Archaeologies: Humans, Animals, Things. London: Routledge, pp. 245-49. Joyce, R.A. \& Gillespie, S.D. eds. 2000. Beyond Kinship: Social and Material Reproduction in House Societies. Philadelphia: University of Pennsylvania Press.

Kalicz, N. \& Makkay, J. 1977. Die Linienbandkeramik in der Großen Ungarischen Tiefebene. Budapest: Akadémiai Kiadó.

Lenneis, E. 2012. Zur Anwendbarkeit des rheinischen Hofplatzmodells im östlichen Mitteleuropa. In: S. Wolfram, H. Stäuble, M. Cladders \& T. Tischendorf, eds. 
Siedlungsstruktur und Kulturwandel in der Bandkeramik. Dresden: Landesamt für Archäologie, pp. 47-52.

Marshall, Y. \& Alberti, B. 2014. A Matter of Difference: Karen Barad, Ontology and Archaeological Bodies. Cambridge Archaeological Journal, 24: 19-36.

McIntosh, R.J. 1974. Archaeology and Mud Wall Decay in a West African Village. World Archaeology, 6: 154-71.

Mímisson, K. \& Magnússon, S.G. 2014. Singularizing the Past: The History and Archaeology of the Small and Ordinary. Journal of Social Archaeology, 14: 3-56.

Naumov, G. 2013. Embodied Houses: The Social and Symbolic Agency of Neolithic Architecture in the Republic of Macedonia. In: D. Hofmann \& J. Smyth, eds. Tracking the House in Neolithic Europe: Sedentism, Architecture and Practice. New York: Springer, pp. 65-94.

Pluckhahn, T. 2010. The Sacred and the Secular Revisited: The Essential Tensions of Early Village Society in the Southeastern United States. In: M.S. Bandy \& J.R. Fox, eds. Becoming Villagers: Comparing Early Village Societies. Tucson: University of Arizona Press, pp. 100-18.

Raczky, P., Anders, A., Sebők, K., Csippán, P. \& Tóth, Zs. 2015. The Times of PolgárCsőszhalom: Chronologies of Human Activities in a Late Neolithic Settlement in Northeastern Hungary. In: S. Hansen, P. Raczky, A. Anders \& A. Reingruber, eds. Neolithic and Copper Age between the Carpathians and the Aegean Sea: Chronologies and Technologies from the 6th to 4th Millennia BCE. Bonn: Habelt, pp. 21-48.

Richards, C. ed. 2005. Dwelling among the Monuments: The Neolithic Village of Barnhouse, Maeshowe Passage Grave and Surrounding Monuments at Stenness, Orkney. Cambridge: McDonald Institute for Archaeological Research.

Robb, J. \& Pauketat, T. 2013. From Moments to Millennia: Theorizing Scale and Change in Human History. In: J. Robb \& T. Pauketat, eds. Big Histories, Human Lives: Tackling Problems of Scale in Archaeology. Sante Fe: School for Advanced Research Press, pp. 333.

Rück, O. 2009. New Aspects and Models for Bandkeramik Settlement Research. In: D.

Hofmann \& P. Bickle, eds. Creating Communities: New Advances in Central European Neolithic Research. Oxford: Oxbow Books, pp. 159-85.

Schier, W. 1996. The Relative and Absolute Chronology of Vinča: New Evidence from the Type Site. In: F. Draşovean, ed. The Vinča Culture, its Role and Cultural Connections. Timişoara: Muzeul Banatului, pp. 141-62. 
Schier, W. 2006. Neolithic House Building and Ritual in the Late Vinča Tell Site of Uivar, Romania. In: N. Tasić \& C. Grozdanov, eds. Homage to Milutin Garašanin. Belgrade: Serbian Academy of Sciences and Arts, pp. 325-39.

Schier, W. 2009. Tell Formation and Architectural Sequence at Late Neolithic Uivar (Romania). In: F. Draşovean, D.L. Ciobotaru \& M. Maddison, eds. Ten Years After: The Neolithic of the Balkans, as Uncovered by the Last Decade of Research. Timişoara: Editura Marineasa, pp. 219-33.

Schier, W., Draşovean, F., Bayliss, A., Gaydarska, B. \& Whittle, A. forthcoming. Scientific Dating and Chronological Modelling. In: F. Draşovean \& W. Schier, Uivar "Gomila" - A Prehistoric Tell Settlement in Romanian Banat. Vol. I: Site, Architecture, Stratigraphy and Dating. Prähistorische Archäologie Südosteuropas 31. Rahden/Westf.: Verlag Marie Leidorf.

Scott, C. 2006. Spirit and Practical Knowledge in the Person of the Bear among Wemindji Cree Hunters. Ethnos, 71: 51-66.

Souvatzi, S. 2008. A Social Archaeology of Households in Neolithic Greece: An Anthropological Approach. Cambridge: Cambridge University Press.

Souvatzi, S. 2012. Space, Place and Architecture: A Major Meeting Point between Social Archaeology and Anthropology? In: D. Shankland, ed. Archaeology and Anthropology Past, Present and Future. London: Berg, pp. 173-96.

Stevanović, M. 2002. Burned Houses in the Neolithic of Southeast Europe. In D. Gheorghiu ed. Fire in Archaeology. British Archaeological Reports International Series 1089.

Oxford: Archaeopress, pp. 55-62.

Stevanović, M. \& Jovanović, B. 1996. Revisiting Vinča-Belo Brdo. Starinar, 47: 193-204. Tasić, N., Marić, M., Penezić, K., Filipović, D., Borojević, K., Borić, D., Cook, G., Reimer, P., Bayliss, A., Barclay, A., Gaydarska, B. \& Whittle, A. 2015. The End of the Affair: Formal Chronological Modelling for the Top of the Neolithic Tell of Vinča-Belo Brdo. Antiquity, 89: 1064-82.

Tasić, N., Marić, M., Beavan, N., Bronk Ramsey, C., Kromer, B., Barclay, A., Bayliss, A., Gaydarska, B. \& Whittle, A. 2016. Vinča-Belo Brdo, Serbia: The Times of a Tell. Germania, 93: 89-157.

Thomas, J. 2015. The Future of Archaeological Theory. Antiquity, 89: 1287-96.

Trigger, B.G. 1976. The Children of Aataentsic: A History of the Huron People to 1660. Montreal \& Kingston: McGill-Queen's University Press. 
Tringham, R. 2005. Weaving House Life and Death into Places: A Blueprint for a Hypermedia Narrative. In: D. Bailey, A. Whittle \& V. Cummings, eds. (Un)settling the Neolithic. Oxford: Oxbow Books, pp. 98-111.

Tringham, R., Brukner, B. \& Voytek, B. 1985. The Opovo Project: A Study of Socioeconomic Change in the Balkan Neolithic. Journal of Field Archaeology, 12: 42544.

van der Veen, M. 2014. The Materiality of Plants: Plant-People Entanglements. World Archaeology, 46: 799-812.

Van Dyke, R.M. 2015. Materiality in Practice: An Introduction. In: R.M. Van Dyke, ed., Practicing Materiality. Tucson: University of Arizona Press, pp. 3-32.

Vigh, H.E. \& Sausdal, D.B. 2014. From Essence back to Existence: Anthropology beyond the Ontological Turn. Anthropological Theory, 14: 49-73.

Waterson, R. 1990. The Living House: An Anthropology of Architecture in South-East Asia.

Oxford: Oxford University Press.

Waterson, R. 2013. Transformations in the Art of Dwelling: Some Anthropological Reflections on Neolithic Houses. In: D. Hofmann \& J. Smyth, eds. Tracking the House in Neolithic Europe: Sedentism, Architecture and Practice. New York: Springer, pp. 373-96. Watts, C. 2013. Relational Archaeologies: Roots and Routes. In: C. Watts, ed. Relational Archaeologies: Humans, Animals, Things. London: Routledge, pp. 1-20.

Wilshusen, R.H. \& Potter, J.M. 2010. The Emergence of Villages in the American Southwest: Cultural Issues and Historical Perspectives. In: M.S. Bandy \& J.R. Fox, eds. Becoming Villagers: Comparing Early Village Societies. Tucson: University of Arizona Press, pp. 165-83.

Zimmermann, A. 2012. Das Hofplatzmodell - Entwicklung, Probleme, Perspektiven. In: S. Wolfram, H. Stäuble, M. Cladders \& T. Tischendorf, eds. Siedlungsstruktur und Kulturwandel in der Bandkeramik. Dresden: Landesamt für Archäologie, pp. 11-19.

\section{BIOGRAPHICAL NOTES}

Florin Draşovean is a senior researcher at the National Museum of Banat, Timișoara, and Professor at the Institute for Doctoral Studies of the Babeș Bolyai University at Cluj-Napoca. His research has centred on the Neolithic and Eneolithic of western and central Romania, his interests including radiocarbon dating, anthropomorphic figurines, burial rites, and longdistance cultural exchanges. 
Address: Institute for Doctoral Studies, Babeş-Bolyai University, Str. Universităţii nr. 7-9, Cluj-Napoca, Romania. [email: fdrasovean2000@yahoo.com]

Wolfram Schier has held a chair in Berlin since 2006, after previous posts in several other German universities. His research is focused on the Neolithic of central and south-east Europe, as well as on the Iron Age, and his interests include settlement and landscape archaeology, multidisciplinary and experimental research on prehistoric agriculture and animal husbandry, and social structure and social change.

Address: Freie Universität Berlin, Fachbereich Geschichts- und Kulturwissenschaften, Institut für Prähistorische Archäologie, Fabeckstr. 23-25, 14195 Berlin, Germany. [email: wolfram.schier@fu-berlin.de]

Alex Bayliss is Head of Scientific Dating at Historic England and Professor of Archaeological Science at the University of Stirling. She has pioneered the routine use of Bayesian statistics for chronological modelling in archaeology, constructing hundreds of models from thousands of radiocarbon dates.

Address: Historic England, 1 Waterhouse Square, 138-142 Holborn, London, UK [email: Alex.Bayliss@HistoricEngland.org.uk]

Bisserka Gaydarska is a research assistant of The Times of Their Lives project in Cardiff University, while her main research activities are fostered by Durham University. Apart from her homeland Bulgaria, she has been involved in various field projects and museum studies in Romania, Greece, Turkey and recently Ukraine. Her research interests include GIS and landscape archaeology, material culture studies (fragmentation, artifact biography), the prehistory of central and eastern Europe, interdisciplinary studies, identity and early urbanism.

Address: Department of Archaeology and Conservation, Cardiff University, John Percival Building, Colum Drive, Cardiff, CF10 3EU, UK. [email: b_gaydarska@yahoo.co.uk]

Alasdair Whittle is a Distinguished Research Professor at Cardiff University, where he has lectured and researched on many aspects of the Neolithic since 1978. He is a Fellow of the British Academy.

Address: Department of Archaeology and Conservation, Cardiff University, John Percival Building, Colum Drive, Cardiff, CF10 3EU, UK. [email: whittle@cardiff.ac.uk] 


\section{La vie des maisons : leur durée, contexte et histoire sur le tell d'Uivar en Roumanie}

La littérature archéologique contient un mélange de différents modèles relatifs à la durée d'occupation des maisons pendant le Néolithique en Europe. Dans cet article nous présentons un sommaire d'un schéma chronologique formel pour le tell néolithique d'Uivar en Roumanie occidentale et établissons un lien entre les estimations de la durée d'occupation des maisons et les autres éléments de l'évolution du tell entre la fin du sixième millénaire et le milieu du cinquième millénaire cal BC. Nous notons trois répercussions de plus grande envergure : qu'il faut étudier les demeures cas par cas, que la durée d'occupation des maisons nous fournit des indications importantes sur les aspects sociaux d'une communauté et que les maisons doivent être intégrées à part entière dans les interprétations et récits concernant le Néolithique, alors que curieusement on les considérait souvent pour acquises en archéologie néolithique. Il reste à savoir dans quelle perspective, qu'elle soit anthropocentrique ou relationnelle, nous pouvons le mieux atteindre ce but ; quoique dans notre cas il nous parait utile d'aborder la question du point de vue de la vie at de la vitalité des demeures, il ne faudra pas pour autant négliger la créativité des personnes et leur capacité de modifier l'histoire. Translation by Madeleine Hummler Mots-clés : maisons néolithiques, durée d'occupation des maisons, tell d'Uivar, Roumanie, datation radiocarbone, modélisation chronologique, approches historiques et relationnelles

\section{Das Leben der Häuser: Dauer, Zusammenhänge und Geschichte auf dem neolithischen Tell von Uivar in Rumänien}

In der archäologischen Literatur gibt es eine erhebliche Vielfalt von verschiedenen Modellen, welche die Lebensdauer der Häuser im europäischen Neolithikum betreffen. In diesem Artikel wird die formelle, chronologische Modellierung des neolithischen Tells von Uivar in Westrumänien zusammengefasst, und unsere Schätzung der Dauer der Hausstrukturen wird mit anderen Elementen der Entwicklung des Tells zwischen dem späten sechsten Jahrtausend bis in die Mitte des fünften Jahrtausends cal BC verbunden. Drei weitere Auswirkungen werden hier besprochen: erstens muss jedes Haus von Fall zu Fall und kontextspezifisch bewertet werden; zweitens liefert die Lebensdauer der Hausstrukturen maßgebliche Einblicke in die Sozialität einer Gemeinschaft; und drittens sollten Häuser, welche die neolithische Archäologie erstaunlich oft eher als selbstverständlich gehalten hat, vollständig in die Interpretation von neolithischen Geschichten eingegliedert werden. Ob eine 
anthropozentrische oder relationale Perspektive die geeignetste Vorgangsweise ist, bleibt eine offene Frage; obschon es in unserem Fall nützlich ist, das Thema vom Blickpunkt des Lebens und Dynamik eines Hauses zu behandeln, dürfen wir den Erfindergeist und die Fähigkeit der Menschen, ihre Geschichte zu verändern, nicht leichthin außer Acht lassen. Translation by Madeleine Hummler

Stichworte: neolithische Häuser, Lebensdauer eines Hauses, Tell von Uivar, ${ }^{14} \mathrm{C}$ Datierung, chronologische Modellierung, historische und relationale Ansätze

\section{Figure captions}

Figure 1. Map showing the location of Uivar.

Figure 2. Geophysical plot of the tell and its surroundings.

Figure 3. Trench 1: the burnt remains of house H4b-1, cut by later pits. [photograph (C) Institut für Prähistorische Archäologie, Freie Universität Berlin].

Figure 4. Trench I: isometric reconstruction of house 4b-1.

[drawing P. Kunz, Institut für Prähistorische Archäologie, Freie Universität Berlin].

Figure 5. Trench IV, South section. Deep ditch 1043 (right), cut into earlier ditches (1238, centre, 1237, left).

[photogrammetry S. Suhrbier, Institut für Prähistorische Archäologie, Freie Universität Berlin].

Figure 6. Probability distributions of dates for buildings and ditch circuits at Uivar, derived from the chronological model defined in Schier et al. (forthcoming, figs 6.9 and 6.12-6.22). For some buildings, insufficient datable material was available to allow their periods of occupation to be estimated securely (in these cases only estimated construction dates are shown).

Figure 7. Durations of building stages in Trench I and II/III at Uivar, derived from the chronological model defined in Schier et al. (forthcoming, figs 6.9 and 6.12-6.22).

Figure 8. Schematic plans showing the development of the Neolithic settlement and defences at Uivar through time. The left-hand column shows the stratigraphic phasing in Trench I, the only trench of the interior of the tell where the buried ancient surface could be reached. The central column shows subsequent phases of the inner fortification system as could be detected in Trench IV at the edge of the visible tell. The right-hand column illustrates the whole settlement with its outer defensive ditches far beyond the visible settlement mound. Vertical lines indicate stratigraphic succession, broken horizontal lines represent relative contemporaneity as suggested by the model defined in Figure 6. 
Figure 9. Reconstruction of the settlement as it may have looked in c. $4800 \mathrm{cal}$ BC.

Table 1

Table 1. Highest Posterior Density interval of dates for the construction and demolition of buildings and the digging of ditch circuits at Uivar, derived from the chronological model defined in Schier et al. (forthcoming, figs 6.9 and 6.12-6.22). The Posterior Density estimates from which these intervals are derived are illustrated in Figures 6 and 7.

\begin{tabular}{|c|c|c|}
\hline \multirow[t]{2}{*}{ Parameter } & \multicolumn{2}{|c|}{ Highest Posterior Density interval } \\
\hline & (95\% probability) & (68\% probability) \\
\hline \multicolumn{3}{|l|}{ Building Stage 5b } \\
\hline build $\mathrm{H} 5 \mathrm{~b}$ & $5230-5125 \mathrm{cal} \mathrm{BC}$ & $\begin{array}{l}5220-5205 \mathrm{cal} \mathrm{BC}(21 \%) \text { or } \\
5180-5140 \mathrm{cal} \mathrm{BC}(47 \%)\end{array}$ \\
\hline end $\mathrm{H} 5 \mathrm{~b}$ & $5220-5115 \mathrm{cal} \mathrm{BC}$ & $\begin{array}{l}5215-5200 \mathrm{cal} \mathrm{BC}(12 \%) \text { or } \\
5170-5125 \mathrm{cal} \mathrm{BC}(56 \%)\end{array}$ \\
\hline use $\mathrm{H} 5 \mathrm{~b}$ & $1-50$ years & $1-20$ years \\
\hline \multicolumn{3}{|l|}{ Building Stage 5a } \\
\hline build H5a & $5205-5100 \mathrm{cal} \mathrm{BC}$ & $5165-5110 \mathrm{cal} \mathrm{BC}$ \\
\hline end $H 5 a$ & $5185-5090 \mathrm{cal} \mathrm{BC}$ & $5150-5100 \mathrm{cal} \mathrm{BC}$ \\
\hline use H5a & $1-45$ years & $1-20$ years \\
\hline \multicolumn{3}{|l|}{ Building Stage 4b } \\
\hline build $H 4 b$ & $5150-5075 \mathrm{cal} \mathrm{BC}$ & $5125-5085 \mathrm{cal} \mathrm{BC}$ \\
\hline end $H 4 b$ & $5100-5045 \mathrm{cal} \mathrm{BC}$ & $5085-5055 \mathrm{cal} \mathrm{BC}$ \\
\hline use $H 4 b$ & $10-70$ years & $20-50$ years \\
\hline \multicolumn{3}{|l|}{ Ditch F1237 } \\
\hline $\operatorname{dig} F 1237$ & $\begin{array}{l}5235-5200 \mathrm{cal} \mathrm{BC}(21 \%) \text { or } \\
5180-5075 \mathrm{cal} \mathrm{BC}(74 \%)\end{array}$ & $\begin{array}{l}5225-5205 \mathrm{cal} \mathrm{BC}(15 \%) \text { or } \\
5170-5115 \mathrm{cal} \mathrm{BC}(53 \%)\end{array}$ \\
\hline \multicolumn{3}{|l|}{ Building Stage 4a } \\
\hline build $\mathrm{H} 4 \mathrm{a}$ & $5090-5035 \mathrm{cal} \mathrm{BC}$ & $5080-5050 \mathrm{cal} \mathrm{BC}$ \\
\hline end $H 4 a$ & $5055-5000 \mathrm{cal} \mathrm{BC}$ & $5045-5010 \mathrm{cal} \mathrm{BC}$ \\
\hline use $\mathrm{H} 4 \mathrm{a}$ & $10-70$ years & $20-50$ years \\
\hline \multicolumn{3}{|l|}{ Building Stage 3d+c } \\
\hline build $H 3 d+c$ & $5045-4990 \mathrm{cal} \mathrm{BC}$ & $5035-5000 \mathrm{cal} \mathrm{BC}$ \\
\hline end $H 3 d+c$ & $5005-4935 \mathrm{cal} \mathrm{BC}$ & $4995-4950 \mathrm{cal} \mathrm{BC}$ \\
\hline use $H 3 d+c$ & $10-85$ years & $20-65$ years \\
\hline \multicolumn{3}{|c|}{ Ditches F1236=F1238 \& F1219 } \\
\hline $\operatorname{dig} F 1236=F 1238$ & $5140-4960 \mathrm{cal} \mathrm{BC}$ & $5075-5000 \mathrm{cal} \mathrm{BC}$ \\
\hline $\operatorname{dig} F 1219$ & $5185-4925 \mathrm{cal} \mathrm{BC}$ & $\begin{array}{l}5165-5095 \mathrm{cal} \mathrm{BC}(23 \%) \text { or } \\
5050-4950 \mathrm{cal} \mathrm{BC}(45 \%)\end{array}$ \\
\hline \multicolumn{3}{|l|}{ Building Stage 3b } \\
\hline build $H 3 b$ & $4985-4910 \mathrm{cal} \mathrm{BC}$ & $4960-4925 \mathrm{cal} \mathrm{BC}$ \\
\hline end $H 3 b$ & $4930-4860 \mathrm{cal} \mathrm{BC}$ & $4920-4875 \mathrm{cal} \mathrm{BC}$ \\
\hline use $H 3 b$ & $15-90$ years & $25-65$ years \\
\hline
\end{tabular}




\begin{tabular}{|c|c|c|}
\hline \multicolumn{3}{|l|}{ Building Stage 3a } \\
\hline build $\mathrm{H3a}$ & $4920-4850 \mathrm{cal} \mathrm{BC}$ & $\begin{array}{l}4905-4895 \mathrm{cal} \mathrm{BC}(8 \%) \text { or } \\
4890-4855 \mathrm{cal} \mathrm{BC}(60 \%)\end{array}$ \\
\hline end $H 3 a$ & $4895-4835 \mathrm{cal} \mathrm{BC}$ & $4865-4840 \mathrm{cal} \mathrm{BC}$ \\
\hline use $H 3 a$ & $1-55$ years & $5-35$ years \\
\hline \multicolumn{3}{|c|}{ Ditches F1055 \& F1158 } \\
\hline $\operatorname{dig} F 1055$ & $5120-4835 \mathrm{cal} \mathrm{BC}$ & $5015-4870 \mathrm{cal} \mathrm{BC}$ \\
\hline $\operatorname{dig} F 1158$ & $5115-4845 \mathrm{cal} \mathrm{BC}$ & $5015-4880 \mathrm{cal} \mathrm{BC}$ \\
\hline \multicolumn{3}{|l|}{ Building Stage 2b } \\
\hline build $H 2 b$ & $4870-4800 \mathrm{cal} \mathrm{BC}$ & $4855-4825 \mathrm{cal} \mathrm{BC}$ \\
\hline end $H 2 b$ & $4790-4725 \mathrm{cal} \mathrm{BC}$ & $4775-4735 \mathrm{cal} \mathrm{BC}$ \\
\hline use $H 2 b$ & $35-125$ years & $55-105$ years \\
\hline \multicolumn{3}{|c|}{ Ditches F1053, F4045=F4051 \& outer circuit; Houses A-C } \\
\hline $\operatorname{dig} F 1053$ & $4855-4755 \mathrm{cal} \mathrm{BC}$ & $4830-4780 \mathrm{cal} \mathrm{BC}$ \\
\hline build House A & $4855-4725 \mathrm{cal} \mathrm{BC}$ & $4830-4755 \mathrm{cal} \mathrm{BC}$ \\
\hline $\operatorname{dig} F 4045=F 4051$ & $4865-4710 \mathrm{cal} \mathrm{BC}$ & $4810-4735 \mathrm{cal} \mathrm{BC}$ \\
\hline dig outer circuit & $\begin{array}{l}4900-4860 \mathrm{cal} \mathrm{BC}(8 \%) \text { or } \\
4855-4720 \mathrm{cal} \mathrm{BC}(87 \%)\end{array}$ & $4840-4755 \mathrm{cal} \mathrm{BC}$ \\
\hline build House B & $4920-4605 \mathrm{cal} \mathrm{BC}$ & $4835-4645 \mathrm{cal} \mathrm{BC}$ \\
\hline build House C & $4820-4730 \mathrm{cal} \mathrm{BC}$ & $4795-4745 \mathrm{cal} \mathrm{BC}$ \\
\hline \multicolumn{3}{|c|}{ Building Stage 2a, Houses 3208 \& 2245} \\
\hline build $H 2 a$ & $4770-4675 \mathrm{cal} \mathrm{BC}$ & $4740-4700 \mathrm{cal} \mathrm{BC}$ \\
\hline TPQ House 3208 & $4770-4600 \mathrm{cal} \mathrm{BC}$ & $4725-4630 \mathrm{cal} \mathrm{BC}$ \\
\hline build House 2245 & $4680-4580 \mathrm{cal} \mathrm{BC}$ & $4665-4610 \mathrm{cal} \mathrm{BC}$ \\
\hline \multicolumn{3}{|c|}{ Ditches F1029, F1043=F1054 \& F2108 \& the palisade in Trench IX } \\
\hline $\operatorname{dig}$ F1029 & $4805-4690 \mathrm{cal} \mathrm{BC}$ & $4775-4715 \mathrm{cal} \mathrm{BC}$ \\
\hline $\operatorname{dig} F 1043=F 1054$ & $4790-4600 \mathrm{cal} \mathrm{BC}$ & $4750-4640 \mathrm{cal} \mathrm{BC}$ \\
\hline $\operatorname{dig} F 2108$ & $\begin{array}{l}4795-4650 \mathrm{cal} \mathrm{BC}(91 \%) \text { or } \\
4640-4620 \mathrm{cal} \mathrm{BC}(4 \%)\end{array}$ & $4770-4685 \mathrm{cal} \mathrm{BC}$ \\
\hline$H d-22971$ & $\begin{array}{l}4790-4650 \mathrm{cal} \mathrm{BC}(93 \%) \text { or } \\
4635-4620 \mathrm{cal} \mathrm{BC}(2 \%)\end{array}$ & $\begin{array}{l}4770-4750 \mathrm{cal} \mathrm{BC}(11 \%) \text { or } \\
4745-4685 \mathrm{cal} \mathrm{BC}(57 \%)\end{array}$ \\
\hline
\end{tabular}

